\title{
Analisa Pemanfaatan Teman Sebaya dalam Perkembangan Belajar Siswa Pada Program Keahlian di SMK PGRI 2 Kota Jambi
}

\author{
Redi Indra Yudha ${ }^{1^{*}}$, Ulul Azmi ${ }^{2}$, Lusi Larasati ${ }^{3}$ \\ Program Studi Pendidikan Ekonomi, FKIP UNBARI \\ "Correspondence email: ilapitanoredi@gmail.com
}

\begin{abstract}
In this study it self will focus more on one extrinsic influence, namely peers. This is based on considerations that at SMK PGRI 2 Jambi City students have chosen their abilities in their own expertise program, while considerations such as environment and classroom management through the use of peer-to-peer approaches have not had much impact on their own learning development, both inside and outside school. Based on the results of descriptive analysis of research where the analysis is used to find out a description of each research variable used, the results obtained by using peer variables are in the good category with a total value of Respondents' Achievement of 81.64. This can indicate that in developing the ability to acquire skills in vocational learning, peer factors have an influence on students' understanding of learning. In the analysis results obtained in the Communalities table itself, it can be seen that the acquisition of the MSA value from the highest point is at P7 (community) of 0.730. Meanwhile, the lowest MSA value was at P2 (relative order) of 0.512. This explains that the student community in group learning plays an active role in improving the abilities and skills of vocational students when carrying out teaching and learning activities both theoretical and practical.
\end{abstract}

Keywords : Peers; Group Learning

\section{PENDAHULUAN}

Di era revolusi industri 4.0 masyarakat saat ini dimana kreatifitas siswa juga harus dibarengi dengan kemampuan Integrasi Information and Communication (ICT), dituntut untuk mempersiapkan diri agar dapat bertahan hidup dan bersaing. Salah satu langkah untuk mempersiapkan diri adalah melalui pendidikan. Hal ini dikarenakan, pendidikan merupakan fase yang tepat bagi peningkatan kualitas hidup masyarakat. Melalui pendidikan seseorang dibina dan dibimbing untuk mampu mengembangkan bakat, minat dan intelektualnya guna untuk persiapan berkarir dimasa depan, dengan pengetahuan, keahlian dan keterampilan seorang manusia mampu menjaga eksistensinya.

Pendidikan adalah usaha sadar untuk menumbuhkembangkan potensi sumber daya manusia melalui kegiatan pengajaran. Penyelenggaraan pendidikan pada sekolah merupakan bentuk penjabaran amanat Undang-Undang Nomor 20 tahun 2003 tentang Sistem Pendidikan Nasional. Hal ini secara jelas dinyatakan bahwa tujuan pendidikan nasional adalah untuk berkembangnya potensi peserta didik agar menjadi manusia yang beriman dan bertaqwa kepada Tuhan Yang Maha Esa, berakhlak mulia, sehat, berilmu, cakap, kreatif, mandiri dan menjadi warga negara yang demokratis serta bertanggung jawab.

Dengan adanya perubahan pendidikan sebagai sarana untuk menyampaikan ilmu tetapi diharapkan adanya perubahan pola kehidupan yang lebih baik. Keberhasilan pendidikan dapat dilihat dari peningkatan kualitas Sumber Daya Manusia (SDM). SDM yang berkualitas akan mampu mengembangkan potensi yang dimiliki untuk kemajuan bangsa dan negara. Salah satu upaya membina dan membangun SDM yang tangguh dan dapat diandalkan diantaranya adalah melalui pendidikan, baik yang diberikan melalui pendidikan formal di sekolah, maupun pendidikan non formal di lingkungan keluarga.

Di luar lingkungan keluarga, anak akan memperhatikan dan memperlihatkan lingkungan sekitarnya terhadap eksistensi mereka, baik dari kemampuan, pengetahuan, maupun pengalaman yang mereka miliki. Hal ini dikarenakan, selain orang tua, siswa akan mencari individu atau grup, maupun kelompok yang sebaya dengan mereka untuk beraktivitas. Teman merupakan lingkungan sosial pertama anak atau remaja untuk belajar berinteraksi dengan orang lain selain anggota keluarga.

Pada masa remaja hubungan teman sebaya lebih dekat ketimbang dengan keluarganya sendiri, hal itu dikarenakan remaja lebih sering lebih berada diluar rumah untuk menghabiskan waktunya, yaitu dengan kegiatan sekolah, kegiatan ekstrakulikuler maupun dengan teman sebayanya. Bagi anak interaksi sosial terjadi pertama kali di dalam keluarga, terutama dengan orang tua. Kemudian seiring dengan perkembangan lingkungan sosial seseorang, interaksi sosial meliputi sosial yang luas seperti sekolah dan dengan teman-teman (Desmita, 2010).

Dalam lingkungan teman sebaya, ada konsep dan cara anak-anak bertindak dengan teman-temannnya. Yang mana kedua hal itu akan berubah seiring dengan bertambahnya usia mencerminkan perkembangan kognitif dan emosi mereka. Teman-teman semasa prasekolah akan bermain bersama, tetapi pertemanan di antara anak-anak usia sekolah akan stabil dan dalam. Anak-anak tidak bisa menjadi atau memiliki teman sejati sampai mereka mencapai kematangan kognitif 
Redi Indra Yudha et al, Analisa Pemanfaatan Teman Sebaya dalam Perkembangan Belajar Siswa Pada Program Keahlian di SMK PGRI 2 Kota Jambi

untuk mempertimbangkan pandangan dan kebutuhan orang lain dan diri mereka sendiri.

Bentuk jenjang pendidikan menengah yang ada di Indonesia sebagai jembatan untuk memasuki dunia kerja adalah Sekolah Menengah Kejuruan (SMK). Sekolah Menengah Kejuruan (SMK) merupakan jenis pendidikan menengah, sebagaimana ditegaskan dalam UndangUndang Sistem Pendidikan Nasional Nomor 20 Tahun 2003 Tentang Jalur, Jenjang dan Jenis Pendidikan. Pada Pasal 15 dan Pasal 18 yang menjelaskan bahwa Sekolah Menengah Kejuruan (SMK) merupakan bentuk pendidikan menengah atas kejuruan. Sekolah Menengah Kejuruan (SMK) menyelenggarakan proses pendidikan yang lebih menekankan pada persiapan peserta didik untuk penguasaan proses pembelajaran secara tuntas dan utuh melalui pembelajaran teori dan melaksanakan praktek kerja atau pembelajaran praktek sebagai pelatihan intensifnya. Sistem penyelenggaraan proses pembelajaran di Sekolah Menengah Kejuruan (SMK) lebih banyak aspek praktek daripada teori.

Sekolah Menegah Kejuruan (SMK) sebagai satuan pendidikan formal pada jenjang pendidikan menengah juga memerlukan interaksi yang baik antara pendidik dan peserta didik. Sekolah Menengah Kejuruan (SMK) bertujuan untuk mempersiapkan siswa yang memiliki keterampilan dan pengetahuan sesuai dengan kebutuhan persyaratan lapangan kerja, mengembangkan potensi diridan mampu beradaptasi dengan lingkungannya. Dengan demikian interaksi pendidik dan peserta didik akan menghasilkan pembelajaran yang berkualitas dalam bentuk penguasaan keterampilan dan pengetahuan yang tercermin dalam prestasi belajar yang maksimal.

Adapun fenomena yang dapat dilihat di SMK PGRI 2 Kota Jambi sampai saat ini adalah siswa jarang mengajak temannya untuk belajar bersama dan pada saat pelajaran kosong lebih senang mengajak bercanda daripada berdiskusi. Selain itu, dukungan yang diberikan oleh teman sebaya justru dukungan yang negatif yaitu tidak saling mengingatkan untuk belajar, mengajak bekerja sama dengan temannya ketika mengerjakan ulangan dan mengajak temannya bercanda pada saat pelajaran berlangsung. Diketahui pula bahwa perempuan ternyata sangat dominan dalam mempelajari ilmu-ilmu kejuruan yang bersifat softskill (ketrampilan lunak) seperti seni dan kerajinan, serta bisnis dan manajemen. Sedangkan, laki-laki ternyata sangat dominan dalam mendalami ilmu-ilmu kejuruan yang berkaitan dengan sektor-sektor teknologi seperti multimedia.

Lingkungan sosial yang hidup di sekitar pribadi atau anak-anak sangat mempengaruhi pembentukan kepribadian. Melalui proses sosialisasi melalui teman sebaya, individu menjadi bagian dari suatu kelompok sosial teman sebaya dimana didalamnya terdapat hubungan yang kuat antar anggotanya. Kelompok sebaya juga berpengaruh baik dalam kehidupan pribadi maupun dalam kehidupan kelompok. Dalam hal ini jelaslah bahwa interaksi sosial teman sebaya dapat memberikan andil pada seseorang dalam mengambil keputusan pribadinya.

Aunurrahman (2011), menjelaskan bahwa "belajar adalah suatu proses yang dilakukan individu untuk memperoleh suatu perubahan tingkah laku yang baru secara keseluruhan, sebagai hasil pengalaman individu itu sendiri di dalam interaksi dengan lingkungannya". Dalyono (2012), mengatakan bahwa "belajar adalah suatu usaha atau kegiatan yang bertujuan mengadakan perubahan di dalam diri seseorang, mencakup perubahan tingkah laku, sikap, kebiasaan, ilmu pengetahuan, keterampilan dan sebagainya". Sementara, Djamarah (2011), mengatakan bahwa "belajar adalah suatu proses usaha yang dilakukan individu untuk memperoleh suatu perubahan tingkah laku yang baru secara keseluruhan, sebagai hasil pengalaman individu itu sendiri dalam interaksi dengan lingkungannya".

Sardiman (2010), mengemukakan bahwa "belajar adalah rangkaian kegiatan jiwa raga, psiko-fisik untuk menuju ke perkembangan pribadi manusia seutuhnya, yang berarti menyangkut unsur cipta, rasa dan karsa, ranah kognitif, afektif, dan psikomotorik". Dengan demikian, dari beberapa uraian pendapat di atas, dapat disimpulkan bahwa belajar adalah proses dimana seseorang atau individu menerima sumber-sumber informasi yang dapat menunjang perkembangan maupun perubahan dirinya sendiri. Dimana, perubahanperubahan tersebut dapat dilihat dari pembentukan moral, sikap, karakter, perubahan tingkah laku, pola pikir, dan lain sebagainya pada ruang lingkup dan lingkungan yang positif.

Teman sebaya adalah salah satu lingkungan belajar yang turut mempengaruhi keberhasilan seorang siswa dalam melaksanakan pembelajarannya. Sebab, selain adanya kesamaan pendapat, ide maupun pola pikir dalam mencapai tujuan yang sama. artinya, setelah menerima pendidikan dari orang tua di lingkungan rumah maupun guru pada saat jam pelajaran di sekolah, seorang anak lebih banyak menghabiskan waktunya bersama dengan teman-temannya. Akan tetapi, yang kurang dari hal tersebut adalah pengawasan agar anak mampu memanfaatkan lingkungan teman sebayanya dalam mencapai hal-hal yang lebih positif.

Novandi dan Djazari (2011), mengungkapkan bahwa "teman sebaya adalah suatu lingkungan yang terdiri dari sekelompok orang yang mempunyai kesamaan sosial, seperti kesamaan tingkat dengan berbagai karakter individu yang mampu mempengaruhi perilaku individu." Hal ini senada dengan Saputro dan Pardiman (2012), yang mengungkapkan bahwa "teman sebaya adalah suatu interaksi dengan orang-orang yang mempunyai kesamaan dalam usia dan status. Baik dalam sosialisasi di sekolah, maupun di lingkungan tempat tinggal siswa itu sendiri."

Santrock (2011), mengemukakan bahwa "pada umumnya, keterlibatan dengan orang lain membuka kesempatan bagi siswa untuk mengevaluasi dan 
memperbaiki pemahaman mereka, saat mereka bertemu dengan pemikiran orang lain, dan saat mereka berpartisipasi dalam pencarian pemahaman bersama. Dimana, pada kondisi siswa sendiri, hubungan antar sesama teman sebayanya akan membawa dampak positif maupun negatif terhadap perkembangan proses belajar mereka".

Dengan demikian, adanya perhatian dan dukungan dari teman seusianya, siswa akan merasa diperhatikan dan menambah kepercayaan diri mereka untuk dapat belajar lebih baik. Disamping itu, dengan adanya kepercayaan diri tersebut, maka motivasi belajar dengan sendirinya akan tumbuh pada siswa. Dengan demikian, peran teman sebaya juga dapat mempengaruhi hasil belajar siswa. Hal ini dapat dikatakan bahwa, dengan adanya dukungan yang diterima maka dapat menciptakan suatu dorongan bagi siswa untuk lebih giat dalam meningkatkan hasil belajar mereka.

\section{METODE}

Desain penelitian ini menggunakan metode penelitian deskriptif dan analisis faktor. Deskriptif yang oleh Syekh (2011), dijelaskan sebagai suatu metode dalam meneliti suatu kelompok manusia, suatu objek, suatu set kondisi suatu sistem pemikiran dengan suatu tujuan untuk membuat deskripsi, gambaran yang sistematis sesuai fakta yang sedang diselidiki. Selanjutnya, dikatakan bahwa jika kita ingin meneliti satu dua aspek yang sudah dipetakan maka kita harus masuk ke dalam penelitian yang lebih mendalam. Gudono (2012), menjelaskan bahwa "Analisis faktor merupakan teknik untuk membantu para peneliti dalam mengidentifikasi konstruk yang sifatnya tidak bisa diukur secara langsung (unobsdervable)". Artinya, analisis ini digunakan agar dapat mengetahui keberadaan ataupun mengenai nilai konstruk-konstruk dari penggunaan variabel atau skala tertentu yang memberikan pertanda mengenai konstruk-konstruk tersebut. Sehingga, penelitian dapat dilakukan lebih lanjut.

\section{HASIL DAN PEMBAHASAN}

Adapun analisa deskriptif terhadap variabel teman sebaya yang dilakukan di SMK PGRI 2 Kota Jambi sehubungan dengan penelitian ini dapat dilihat pada tabel, sebagai berikut:

Tabel 1. Distribusi Frekuensi Variabel Teman Sebaya

\begin{tabular}{|c|c|c|c|c|c|c|c|}
\hline No. & Indikator & No. Item & $\mathbf{F}$ & Skor Total & Rerata & TCR $(\%)$ & Kategori \\
\hline 1. & Domain Perkembangan Anak & $1-2$ & 148 & 561 & 4,19 & 83,37 & Baik \\
\hline 2. & Urutan yang Relatif & $3-4$ & 148 & 577 & 4,30 & 86,04 & Baik \\
\hline 3. & Variasi Individual & $5-6$ & 148 & 549 & 4,10 & 81,94 & Baik \\
\hline 4. & Konteks Sosial dan Kultural & $7-8$ & 148 & 528 & 3,94 & 78,73 & Cukup Baik \\
\hline 5. & Pembelajar Aktif & $9-10$ & 148 & 521 & 3,89 & 77,76 & Cukup Baik \\
\hline 6. & Kesempatan & $11-12$ & 148 & 512 & 3,82 & 76,42 & Cukup Baik \\
\hline 7. & Komunitas & $13-14$ & 148 & 541 & 4,03 & 80,67 & Baik \\
\hline 8. & Lingkungan Mikrosistem & $15-16$ & 148 & 516 & 3,85 & 77,01 & Cukup Baik \\
\hline \multicolumn{4}{|c|}{ Rata-rata Variabel } & 547 & 4,08 & 81,64 & Baik \\
\hline
\end{tabular}

Sumber: Data Diolah, 2020.

Berdasarkan tabel di atas, dapat diketahui bahwa faktor-faktor yang mempengaruhi teman sebaya siswa dalam meningkatkan pengetahuan dan kemampuan belajar program keahlian secara keseluruhan berada pada kategori baik. Artinya, dalam meningkatkan keterampilan siswa dalam melaksanakan kegiatan belajar mengajar terkait dengan program keahlian mereka, bantuan dari teman sebaya sangat diperlukan. Lebih lanjut, dalam melakukan proses ekstraksi ini metode yang digunakan adalah Principal Component Analysis. Untuk lebih jelasnya dapat dilihat pada tabel, sebagai berikut:

Tabel 2. Faktoring dan Rotasi Communalities

\begin{tabular}{|l|r|r|}
\hline & Initial & Extraction \\
\hline P1 & 1.000 & .685 \\
P2 & 1.000 & .512 \\
P3 & 1.000 & .618 \\
\hline
\end{tabular}

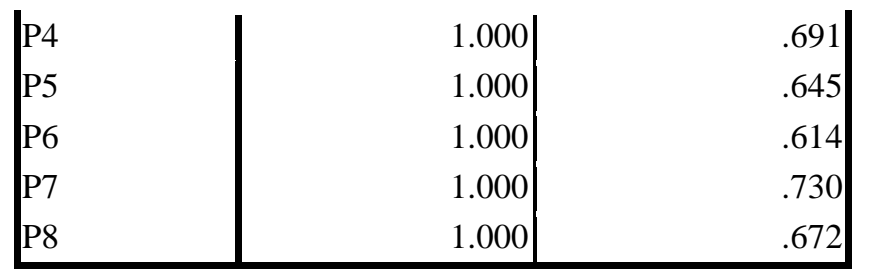

Extraction Method: Principal Component Analysis.

Berdasarkan tabel di atas, dapat dijelaskan bahwa variabel-variabel yang ada dapat dijelaskan di dalam faktor yang terbentuk. Semakin besar nilai Communalities, maka semakin erat hubungannya dengan faktor yang terbentuk. Dalam melihat faktor yang terbentuk, maka harus dapat dilihat pada nilai Eigenvaluennya, dimana nilai tersebut harus berada di atas satu (1). Apabila Eigenvaluen menunjukkan kepentingan relatif masing-masing faktor dalam menghitung varian dari total variabel yang ada, dan susunannya selalu diurutkan pada nilai yang terbesar sampai yang terkecil. Dimana, dapat dilihat pada tabel, sebagai berikut: 
Redi Indra Yudha et al, Analisa Pemanfaatan Teman Sebaya dalam Perkembangan Belajar Siswa Pada Program Keahlian di SMK PGRI 2 Kota Jambi

Tabel 3. Nilai Eigenvalue Masing-masing Variabel Penelitian

Total Variance Explained

\begin{tabular}{|c|c|c|c|c|c|c|c|c|c|}
\hline \multirow[b]{2}{*}{ Component } & \multicolumn{3}{|c|}{ Initial Eigenvalues } & \multicolumn{3}{|c|}{ Extraction Sums of Squared Loadings } & \multicolumn{3}{|c|}{ Rotation Sums of Squared Loadings } \\
\hline & Total & $\begin{array}{c}\% \text { of } \\
\text { Variance }\end{array}$ & Cumulative $\%$ & Total & $\begin{array}{c}\% \text { of } \\
\text { Variance }\end{array}$ & Cumulative $\%$ & Total & $\begin{array}{c}\% \text { of } \\
\text { Variance }\end{array}$ & $\begin{array}{c}\text { Cumulative } \\
\%\end{array}$ \\
\hline 1 & 12.546 & 29.870 & 29.870 & 12.546 & 29.870 & 29.870 & 5.603 & 13.341 & 13.341 \\
\hline 2 & 2.856 & 6.801 & 36.671 & 2.856 & 6.801 & 36.671 & 4.014 & 9.558 & 22.899 \\
\hline 3 & 2.165 & 5.155 & 41.826 & 2.165 & 5.155 & 41.826 & 3.977 & 9.470 & 32.369 \\
\hline 4 & 1.795 & 4.274 & 46.100 & 1.795 & 4.274 & 46.100 & 3.773 & 8.982 & 41.351 \\
\hline 5 & 1.452 & 3.456 & 49.556 & & & & & & \\
\hline 6 & 1.425 & 3.393 & 52.949 & & & & & & \\
\hline 7 & .913 & 4.803 & 72.588 & & & & & & \\
\hline 8 & .794 & 4.177 & 76.765 & & & & & & \\
\hline
\end{tabular}

Extraction Method: Principal Component Analysis.

Adapun untuk mengetahui bagaimana uji variabel yang akan digunakan dalam analisis faktor ini sendiri adalah dengan menggunakan uji nilai KMO dan Bartlett Test dan MSA (Measures of Sampling Adequancy). Dimana, nilai MSA harus di atas 0,5. Adapun untuk lebih jelasnya dapat dilihat pada tabel, sebagai berikut:

Tabel 4. KMO dan Bartlett's Test

KMO and Bartlett's Test

\begin{tabular}{|c|c|c|}
\hline \multicolumn{2}{|c|}{$\begin{array}{l}\text { Kaiser-Meyer-Olkin Measure of Sampling } \\
\text { Adequacy. }\end{array}$} & .722 \\
\hline Bartlett's Test of Sphericity & Approx. Chi-Square & 334.769 \\
\hline & Df & 120 \\
\hline & Sig. & .000 \\
\hline
\end{tabular}

Berdasarkan tabel di atas, dapat dilihat bahwa nilai KMO (Kaiser-Meyer-Olkin) Measures of Sampling Adequancy adalah sebesar 0,722 dengan nilai signifikansi sebesar 0,000. Sementara, nilai Bartlett's Test of Sphericity adalah sebesar 171.

\section{Pembahasan}

\section{Gambaran Faktor-Faktor yang Mempengaruhi Teman Sebaya dalam Pembelajaran Pada Program Keahliannya Di SMK PGRI 2 Kota Jambi}

Berdasarkan hasil analisis deskriptif penelitian dimana analisis tersebut digunakan untuk mengetahui gambaran mengenai masing-masing variabel penelitian yang digunakan, maka didapatkan hasil dengan menggunakan variabel teman sebaya berada pada kategori baik dengan nilai Total Capaian Responden sebesar 81,64. Hal ini dapat mengindikasikan bahwa dalam mengembangkan kemampuan untuk memperoleh keterampilan dalam belajar kejuruan, faktor teman sebaya memiliki pengaruh terhadap pemahaman belajar siswa.

Menurut hasil penelitian Yudha (2015), yang menjelaskan bahwa pengaruh sosial seperti teman sebaya berperan sebagai model, strategi instruksi atau umpan balik (elemen lingkungan untuk siswa) dapat berpengaruh pada factor pribadi siswa seperti tujuan, kepekaan efikasi untuk tugas (menjelaskan bagian berikutnya dari pelajaran), atribusi (keyakinan tentang kesuksesan dan kegagalan), dan proses regulasi-diri seperti perencanaan, monitor diri dan kendali terhadap gangguan. Dimana, model interaksi antara lingkungan, individu, dan perilaku merupakan interaksi timbal balik yang saling menentukan sehingga pada proses tersebut, regulasi-diri dalam terciptanya pencapaian hasil belajar yang optimal dapat terjadi.

Pada instansi pendidikan yang menaungi pendidikan kejuruan tentu memiliki capaian pembelajaran yang cenderung sedikit berbeda dengan sekolah umum lainnya. Hal ini dikarenakan, pada kejuruan siswa lebih dituntut untuk mengembangkan kemampuan mereka baik softskill maupun hardskill yang pada akhirnya akan membuat siswa bekerja secara maksimal. Oleh karena itu, peran teman sebaya sangat dibutuhkan dalam membangun jiwa kerjasama dan saling bertanggung jawab dalam mengikuti kegiatan pembelajaran yang berlangsung di sekolah maupun di lapangan saat melaksanakan Praktek Kegiatan Lapangan (PKL).

Santrock (2011), yang mengemukakan bahwa "pada umumnya, keterlibatan dengan orang lain membuka kesempatan bagi siswa untuk mengevaluasi dan memperbaiki pemahaman mereka, saat mereka bertemu dengan pemikiran orang lain, dan saat mereka berpartisipasi dalam pencarian pemahaman bersama. Dimana, pada kondisi siswa sendiri, hubungan antar sesama teman sebayanya akan membawa dampak positif maupun negatif terhadap perkembangan proses belajar mereka". 
Redi Indra Yudha et al, Analisa Pemanfaatan Teman Sebaya dalam Perkembangan Belajar Siswa Pada Program Keahlian di SMK PGRI 2 Kota Jambi

Faktor-Faktor yang Dipertimbangkan Oleh Siswa dalam Memilih Teman Sebaya dalam Pembelajaran Pada Program Keahliannya Di SMK PGRI 2 Kota Jambi

Berdasarkan hasil penelitian yang telah dilakukan dengan data-data yang dikumpulkan baik melalui kuesioner dan proses pengumpulan data terpisah (wawancara, observasi, dan dokumentasi) dapat diihat bahwa dari indikator variabel teman sebaya, domain perkembangan anak, urutan yang relatif, variasi individual, dan komunitas berada pada kategori baik. Sementara, konteks sosial dan kultural, pembelajar aktif, kesempatan, dan lingkungan mikrosistem berada pada kategori cukup baik.

Hal ini senada dengan hasil penelitian Saputro dan Pardiman (2012), yang menjelaskan bahwa lingkungan teman sebaya merupakan suatu interaksi dengan orangorang yang mempunyai kesamaan dalam usia dan status. Intensitas pertemuan antar siswa di sekolah juga mempunyai pengaruh besar dalam suasana pembelajaran di sekolah. Teman sebaya mampu memberikan motivasi suasana yang membangun apabila berada dalam kelas. Siswa cenderung lebih nyaman dan terbuka apabila bertanya mengenai materi pokok bahasan kepada teman sebaya dibandingkan kepada guru. Hal ini disebabkan muncul suatu ketakutan tersendiri dari siswa ketika bertanya kepada guru.

Pada hasil analisa yang diperoleh pada tabel Communalities sendiri dapat dilihat perolehan nilai MSA dari poin tertinggi berada pada P7 (komunitas) sebesar 0,730. Sementara, perolehan nilai MSA terendah berada pada P2 (urutan yang relatif) sebesar 0,512. Hal ini menjelaskan bahwa komunitas siswa dalam belajar kelompok berperan aktif dalam meningkatkan kemampuan dan keterampilan siswa kejuruan saat melaksanakan aktivitas belajar mengajar baik yang bersifat teoritis maupun praktek.

\section{SIMPULAN}

Dari uraian hasil penelitian dan pembahasan penelitian sebagaimana yang diuraikan pada Bab sebelumnya, maka dapat ditarik beberapa kesimpulan, antara lain sebagai berikut:

1. Sebaran perolehan data mengenai gambaran teman sebaya didapatkan hasil yang berada pada kategori baik dengan nilai Total Capaian Responden sebesar 81,64 . Artinya, teman sebaya dapat memberikan kesan positif terhadap pembelajaran apabila siswa mampu mengembangkan kerjasama.

2. Berdasarkan analisis data pada hasil penelitian dapat dijelaskan bahwa faktor komunitas lebih dominan dengan perolehan nilai sebesar 0,730 . Artinya, siswa akan merasa lebih nyaman berteman atau membentuk kelompok belajar dengan komunitas yang benar-benar memiliki kesamaan, baik dalam aktivitas akademik maupun non akademik.

\section{DAFTAR PUSTAKA}

Aunurrahman. 2011. Belajar dan Pembelajaran. Bandung: CV. Alfabeta.

Dalyono, M. 2012. Psikologi Pendidikan. Jakarta: PT. Rineka Cipta.

Djamarah. 2013. Strategi Belajar Mengajar. Jakarta: Rineka Cipta.

Desmita. 2010. Psikologi Perkembangan Peserta Didik. Bandung: PT. Remaja Rosda Karya.

Gudono. 2012. Analisis Data Multivariat: Edisi Kedua. Yogyakarta : BPFE.

Hamalik, Oemar. 2008. Perencanaan Pengajaran Berdasarkan Pendekatan Sistem. Jakarta: Bumi Aksara.

Novandi \& M. Djazari. 2011. "Pengaruh Motivasi Belajar dan Lingkungan Teman Sebaya Terhadap Prestasi Belajar Akuntansi Keuangan Siswa Kelas XI Ak SMK Negeri 7 Yogyakarta Tahun Ajaran 2011/2012". Kajian Pendidikan Akuntansi Indonesia, Universitas Negeri Yogyakarta. Hal : $1-20$.

Santrock. John. W. 2011. Psikologi Pendidikan "Educational Psychology": Edisi Kedua. Penerjemah: Tri Wibowo B.S. Jakarta: Kencana Prenada Media Group.

Sardiman. 2010. Interaksi dan Motivasi Belajar Mengajar. Jakarta: Rajawali Pers.

Saputro, S.T \& Pardiman. 2012. "Pengaruh Disiplin Belajar Dan Lingkungan Teman Sebaya Terhadap Prestasi Belajar Mahasiswa Program Studi Pendidikan Akuntansi Angkatan 2009 Fakultas Ekonomi Universitas Negeri Yogyakarta”. Jurnal Pendidikan Akuntansi Indonesia, Vol. X, No. 1, Tahun 2012, Universitas Negeri Yogyakarta, Hal : 78-97.

Syekh, Sayid. 2011. Pengantar Statistik Ekonomi Sosial. Jakarta: Gaung Persada.

Undang-Undang RI Nomor 20 Tahun 2003 Tentang Sistem Pendidikan Nasional. Jakarta: Direktorat Jendral Pendidikan Islam Departemen Agama RI, 2006.

Yudha, Redi Indra. 2015. Pengaruh Lingkungan Sekolah, Teman Sebaya Dan Motivasi Belajar Terhadap Hasil Belajar Siswa Pada SMK Bidang Manajemen Bisnis Jurusan Pemasaran Di Kecamatan Jambi Selatan Kota Jambi. Jurnal Ilmiah Dikdaya, Vol. 2, No. 2, 2015. 